\title{
Pemanfaatan Teknologi Sebagai Edukasi Dan Inovasi Pengembangan Masyarakat di Masa Pandemi Covid-19
}

\author{
Desmira $^{1}$, Didik Aribowo ${ }^{2}$, Ratna Ekawati ${ }^{3}$ \\ ${ }^{1,2,3}$ Pendidikan Teknik Elektro, Fakultas Keguruan dan Ilmu Pendidikan \\ Universitas Sultan Ageng Tirtayasa, Serang 42117, Indonesia
}

e-mail: 1desmira@untirta.ac.id, 2d_aribowo@untirta.ac.id, ${ }^{3}$ ratnaekawati@untirta.ac.id

\begin{abstract}
Abstrak
Diera digitalisasi pemanfaatan teknologi sangat memegang peran penting dalam penyampain informasi kepada masyarakat. Pengabdian pada masyarakat merupakan salah satu kegiatan tridarma perguruan tinggi yang merupakan salah satu bentuk pengabdian dosen dan mahasiswa kepada masyarakat kegiatan ini dilaksanakan didesa padarincang dan pabuaran. Kegiatan pengabdian ini dengan mengkalaborasikan kegiatan yang diadakan oleh dosen dengan kelompok KKM 18 Untirta. Tujuan dari kegiatan ini adalah bagaimana memanfaatkan teknologi sebagai edukasi dan inofasi pengembangan masyarakat di masa pandemi covid 19. Ada 5 kegiatan yang dilaksanakan diantaranya Membagikan masker dan poster tentang protokol kesehatan, Video Tubing, Pembuatan Konten Inovasi Tanaman Hidroponik, Webinar dan Pemasangan Banner, dari 5 kegiatan tersebut Video Konten Inovasi tanaman hidroponik lebih diminati dimasyarakat sekitarnya. Tujuan dari kegiatan pengabdian di padarincang dan pabuaran adalah mengetahui minat dari masyarakat sekitar tentang pemanfaatan teknologi dimasa pandemic covid 19. Metode yang diterapkan dalam pemanfaatan teknologi sebagai edukasi dan inovasi pengembangan masyarakat di masa pandemi covid 19, observasi ( dilakukan sebelum kegiatan dilaksanan), wawancara ( dilakukan dengan perangkat desa dan masyarakat sekitarnya), pemanfaatan teknologi dengan melakukan penyuluhan secara daring (YouTube, Twitter, Instagram dan Facebook.). Dari 5 kegiatan tersebut pembuatan Video Konten Inovasi tanaman hidroponik memiliki nilai lebih tinggi yaitu 97\% dari kegiatan yang dilaksanakan tingkat keberhasilan lebih tinggi dari kegiatan yang lain
\end{abstract}

Kata Kunci: memanfaatkan teknologi sebagai edukasi, video inovasi tanaman hidroponik, Pandemi covid 19

\section{Abstract}

The era of digitizing the use of technology plays an important role in delivering information to the public. Community service is one of the tridarma tertiary activities which is a form of devotion for lecturers and students to the community. This activity is carried out in Padarincang and Pabuaran villages. This service activity collaborates the activities held by the lecturer with the KKM 18 Untirta group. The purpose of this activity is how to use technology as education and innovation for community development during the Covid 19 pandemic. There are 5 activities carried out including distributing masks and posters on health protocols, Video Tubing, Creating Hydroponic Plant Innovation Content, Webinars and Banner Installation, of 5 In this activity, the Innovation Video Content of hydroponic plants is more popular in the surrounding community. The purpose of the service activities in Padarincang and Pabuaran is to find out the interest of the surrounding community regarding the use of technology during 
the Covid 19 pandemic. The methods applied in the use of technology as education and community development innovation during the Covid 19 pandemic, observation (conducted before the activity is carried out), interviews ( conducted with village officials and surrounding communities), the use of technology by conducting online counseling (YouTube, Twitter, Instagram and Facebook.). Of the 5 activities, the making of Hydroponic plant Innovation Content Videos has a higher value, namely $97 \%$ of the activities carried out, the success rate is higher than other activities

Keywords: utilizing technology as education, hydroponic plant innovation videos, Covid 19 pandemic

\section{Pendahuluan}

Kecamatan Padarincang Kabupaten Serang-Banten adalah daerah yang memiliki beragam tempat wisata alam yang sangat berpotensi dikembangkan untuk peningkatan ekonomi masyarakat sekitar mulai dari Wisata Air Terjun Curug Cigumawang, Wisata Tubing dan permainan alam Cikal Adventure, Pemandian Air panas batukuwung, Pemandian Air Cirahab, Curug Cikotak dan Bukit Farm Waru Wangi. Selain itu, Padarincang memiliki Insfratruktur jalan yang sangat bagus untuk menunjang akses wisata tersebut (Rahayuningsih et al., 2019).

Selain menyimpan kekayaan wisata Kecamatan Padarincang juga memiliki pusat Ekonomi masyarakat yakni Pasar Padarincang yang selalu dipadati oleh pedagang dan masyarakat (Hariyanto, 2020). Dimana kegiatan ekonomi yang terus berputar diharapkan selalu menjadi penopang ekonomi bagi masyarakat kecil di kecamatan Padarincang (Saruri, 2018).

Kondisi kecamatan Padarincang disaat pandemic covid 19 tidak terlalu terdampak baik itu secara ekonomi karena segala aktifitas ekonomi masih berjalan seperti biasanya tetapi sangat terdampak secara Pendidikan Karena sekolah-sekolah yang berada di daerah padarincang belum bisa melakukan pembelajaran tatap muka secara efektif.

Untuk pelaksaan pengabdian saat ini merupakan kerja sama dengan mahasiswa KKM 18 untirta, kondisi pandemi covid 19 maka kerja sama dilakukan dengan mahasiswa yang berada diwilayah sekitar tempat mereka hal ini dilakukan berdasarkan kebijakan pemerintah dalam menangani covid 19 saat ini masih berlangsung. Kecamatan Pabuaran adalah salah satu dari 29 kecamatan di Kabupaten Serang (Nala \& Indriani, 2020). Kecamatan Pabuaran Terletak disebelah selatan Kab. Serang. Pada awalnya Kecamatan Pabuaran adalah pemekaran dari Kecamatan Ciomas pada saat itu dibawah Keresidenan Banten dan Kewedanan Ciomas, akan tetapi seiring berjalanya waktu Kecamatan Pabuaran dimekarkan dengan Kecamatan Gubungsari (Wisata, Di, Bumi, \& Studi, 2019). Kecamatan Pabuaran memiliki luas wilayah $\pm 4042 \mathrm{Ha}$, dan jumlah penduduk 40216 Jiwa. Masyarakat Kecamatan Pabuaran Kabupaten Serang Secara Umum bermata Pencaharian Petani dan buruh Tani, disamping sebagian ada yang menjadi pengusaha, PNS, TNI, POLRI dan lainnya. Agama yang dianut mayoritas (100\%) Islam dengan banyaknya Pengajian Baik di Tingkat kecamatan, Desa dan Kampung, bahasa yang digunakan adalah bahasa Sunda (Serang) dan Bahasa Jawa (Serang), kultur dan budaya yang berkembang di masyarakat kecamatan Pabuaran sangat dipengaruhi kegiatan keagamaan diantaranya Maulidan, Jamiatu Syahriah, Rajaban dan Haul, pada umumnya budaya masyarakat di kecamatan Pabuaran tidak banyak jauh beda dengan kecamatan lain di kabupaten Serang. Seni Budaya Budaya yang berkembang di Pabuaran Adalah pencak Silat, Debus, Marawis, Kosidah Rudat dan lainnya. 
Tabel 1. Kegiatan dan pelaksanaan pengabdian

\begin{tabular}{|c|c|c|}
\hline No & Nama Kegiatan & Waktu Pelaksanaan \\
\hline 1. & $\begin{array}{l}\text { Membagikan masker dan poster } \\
\text { tentang protokol kesehatan }\end{array}$ & $\begin{array}{l}\text { Pelaksanaan kegiatan dilakukan selama seminggu, mulai dari } \\
\text { tanggal } 22-28 \text { Juli } 2020\end{array}$ \\
\hline 2. & Video Tubing & $\begin{array}{l}\text { Pelaksanaan kegiatan dilakukan selama } 14 \text { hari, pada tanggal } 29 \\
\text { Juli-12 Agustus } 2020\end{array}$ \\
\hline 3. & $\begin{array}{l}\text { Pembuatan Konten Inovasi Tanaman } \\
\text { Hidroponik }\end{array}$ & $\begin{array}{l}\text { Pelaksanaan kegiatan dilakukan selama } 16 \text { hari, mulai dari } \\
\text { tanggal } 23 \text { Juli- } 7 \text { Agustus } 2020\end{array}$ \\
\hline 4. & Webinar & Kegiatan ini dilaksanakan pada tanggal 17 Agustus 2020 \\
\hline 5. & Pemasangan Banner & Kegiatan ini dilaksanakan pada tanggal 19 Agustus \\
\hline
\end{tabular}

Membagikan masker dan poster tentang protokol kesehatan teknik pelaksanaa kegiatan ini adalah poster tentang protokol kesehatan ini akan dibagikan di daerah pemukiman dan membagikan masker sebanayak 30 buah setiap kecamatan, kami bekerja sama dengan Kades dan Camat yang ada di Kecamatan Pabuaran dan Padarincang. Diharapkan dengan adanya poster tersebut, maka masyarakat yang berada di sekitar Kecamatan Pabuaran dan Padarincang dapat memahami dan melakukan protokol kesehatan COVID-19 New Normal.

Video Tubing berisi berbagai tempat wisata yang ada di Kabupaten Serang yang bisa dikunjungi oleh masyarakat sekitar,

\section{Metode}

Metode penelitian yang diterapkan dalam penelitian ini adalah :

a. Observasi

Observasi merupakan metode yang digunakan oleh penulis dengan datang ketempat lokasi pengabdian secara langsung.

Metode penelitian yang diterapkan dalam penelitian ini adalah :

a. Observasi

Observasi merupakan metode yang digunakan oleh penulis dengan datang ketempat lokasi pengabdian secara langsung(Devet, 1990) (Papini, Studies, \& Building, 1988) (Cohen, Manion, Morrison, \& Publishers, 2014).

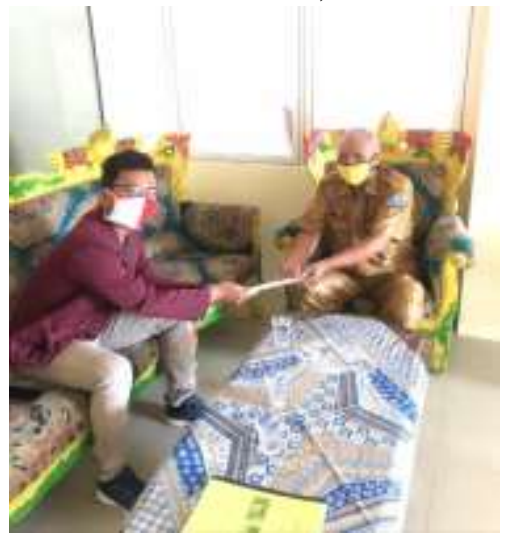

Gambar 1. Tahapan observasi salah satunya dengan melakukan silahturahmi dengan perangkat desa 


\section{ABDITEKNIKA}

Jurnal Pengabdian Kepada Masyarakat

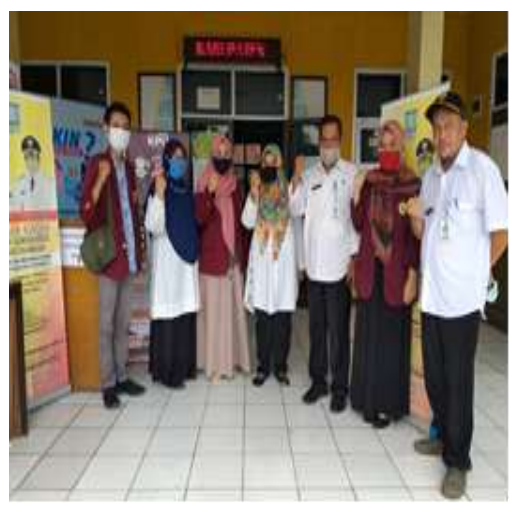

Gambar 2. Silahturami dengan berkunjung kekantor desa padarincang dan pabuaran

b. Wawancara

Tahapan wawancara dilakukan dengan perangkat desa terkait dengan masalah dan kendala yang ada di desa padarincang dan pabuaran dalam menghadapi masa covid 19 dalam rangka menuju new normal

c. Pemanfaatan Teknologi

Pemanfaatan teknologi maksudnya disini adalah dari 5 kegiatan yang dilaksanakan dengan menggunakan berbagai media seperti youtupe, intragram, google meet dan lain, kegiatan.

\section{Hasil dan Pembahasan}

Membagikan masker dan poster tentang protokol kesehatan.

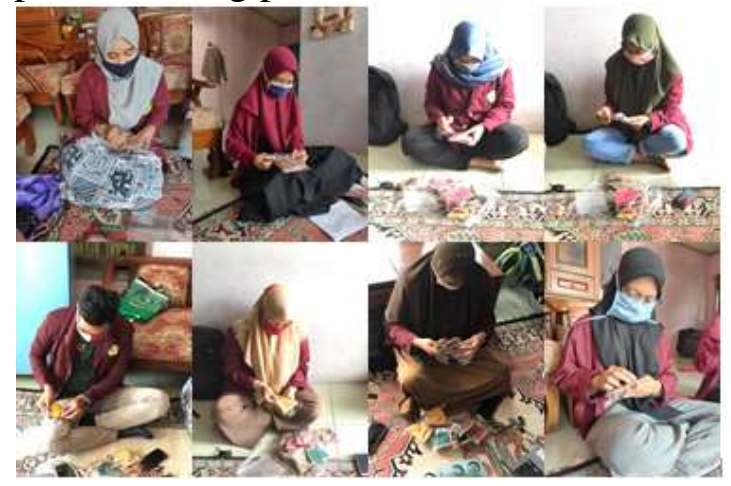

Gambar 3. Pemesanan dan Pengemasan Masker

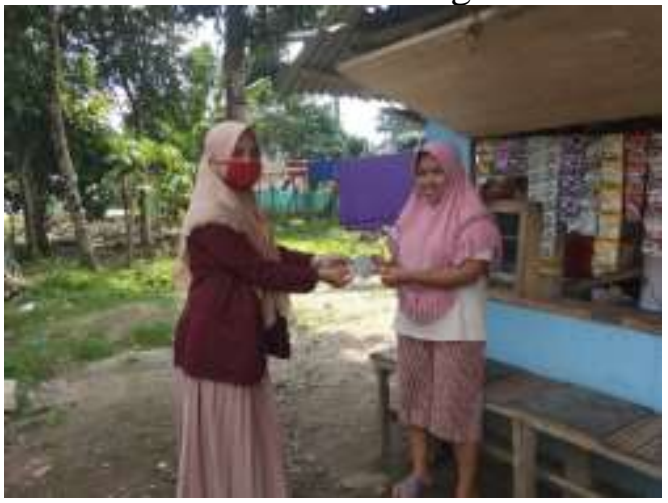

Gambar 4. Pembagian Masker kepada Warga melalui RT Setempat

Video Tubing berisi berbagai tempat wisata yang ada di Kabupaten Serang yang bisa dikunjungi oleh masyarakat sekitar, khususnya masyarakat Kabupaten Serang dan umumnya. 


\section{ABDITEKNIKA}

Jurnal Pengabdian Kepada Masyarakat

seluruh warga Indonesia. penyebaran video melalui media sosial Pembuatan video tubing ini, kami bekerja sama dengan Kades dan Camat setempat serta pengelola tempat wisata tersebut.

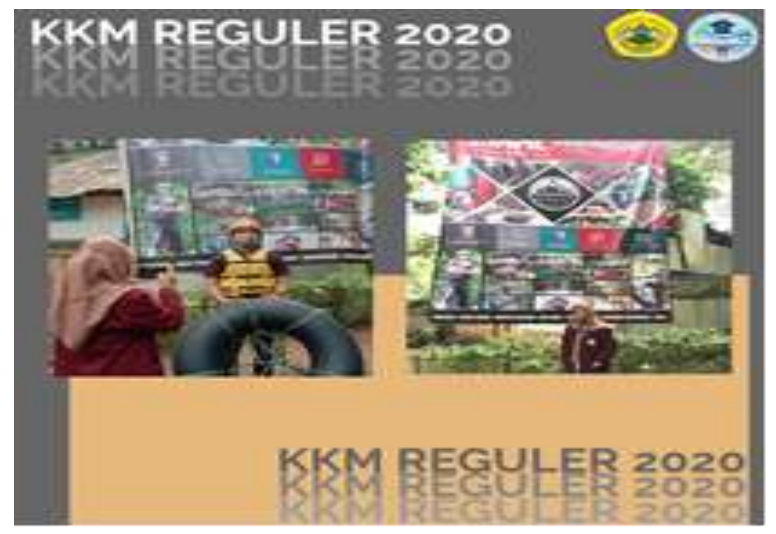

Gambar 5. Pembuatan Video tubing

Video Konten Inovasi tanaman hidroponik adalalah salah satu bentuk inovasi cara menanam sayuran dengan mudah dan praktis. Video dibuat dalam bentuk kumpulan informasi cara menanam tanaman hidroponik di rumah. Konten ini akan disebar melalui media social.

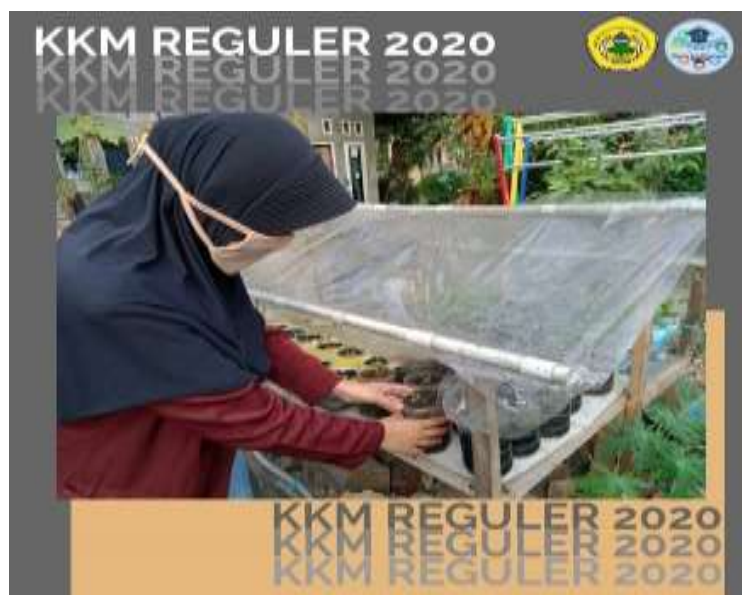

Gambar 6. Shooting Video Tutorial Budidaya Tanaman Hidroponik Dirumah

Webinar dilaksanakan dengan menghadirkan pemateri dari pihak puskesmas/pihak terkait yang menangani pandemi covid-19 dengan mengedukasi pentingnya pencegahan penyebaran covid19. Dilaksanakan dengan menggunakan fasilitas Google Meet.

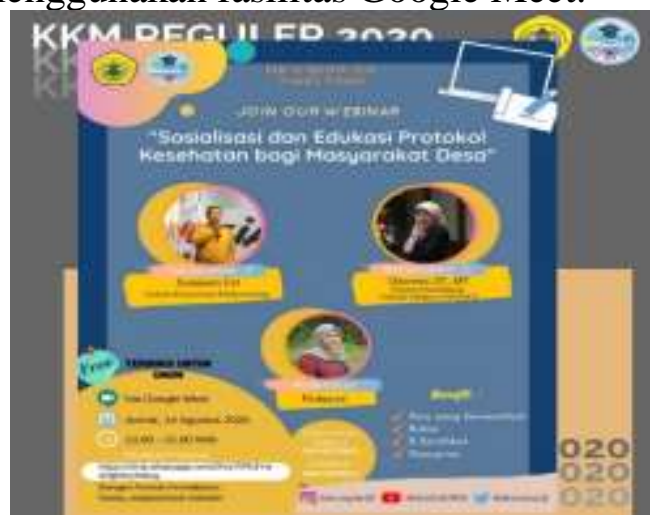

Gambar 7. Penyebaran Pamflet Webinar 
Memasangkan banner di kecamatan padarincang dan kecamatan pabuaran dengan memilih tempat strategis misalkan alun-alun atau pasar atau pusat keramaian.

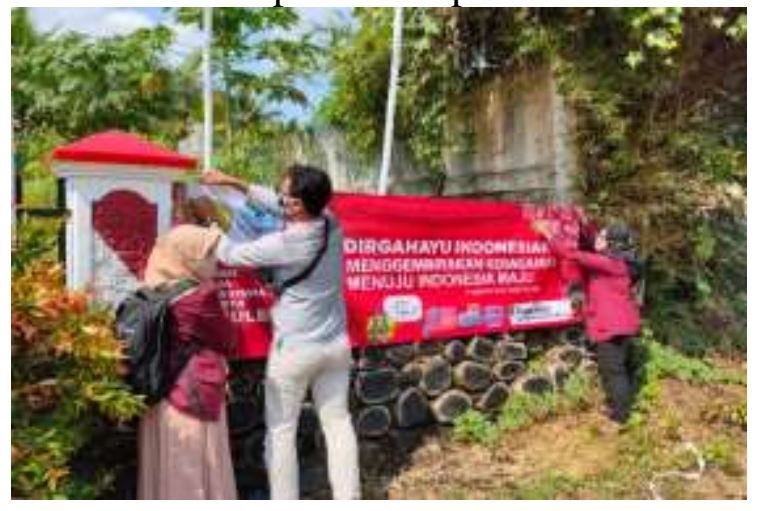

Gambar 8.Pemasangan Banner dikecamatan padarincang

Dalam 5 kegiatan yang dilaksanakan dimasa pandemic ini didapatkan data Membagikan masker dan poster tentang protokol kesehatan manfaat yang dirasakan $80 \%$ responden menyatakan sangat terbantu dengan pembagaian masker juga lebih paham terhadap poster yang dibuat tentang penyebaran covid 19 . Video Tubing manfaat yang dirasakan dalam membantu promosi dari salah satu tempat wisata yang ada dipadarincang adalah $95 \%$ responden menyatakan sangat tertarik untuk berkungjung ke Cikal Adventure setelah menonton video, Pembuatan Konten Inovasi Tanaman Hidroponik, 97\% responden menyatakan sangat tertarik dengan kegiaatan yang dilaksanakan. Webinar $96 \%$ dari peserta merasa senang dengan diadakan acaranya seminar menggunakan google meet, Pemasangan Banner $87 \%$ responden menyatakan pemanfaatan yang dirasakan.

Tabel 2. Tingkat keberhasilan Kegiatan

\begin{tabular}{clcc}
\hline No & \multicolumn{2}{c}{ Nama Kegiatan } & Tingkat keberhasilan kegiatan \\
\hline 1. & $\begin{array}{l}\text { Membagikan masker dan poster tentang } \\
\text { kesehatan }\end{array}$ & $80 \%$ \\
2 & Video Tubing & $95 \%$ \\
3 & Pembuatan konten inovasi tanaman hidroponik & \\
4. & Webinar & $97 \%$ \\
5. & Pemasangan Banner & $96 \%$ \\
\hline
\end{tabular}

\section{1) Target}

Target akhir dari kegiatan ini adalah sejauh mana kegiatan pengabdian yang dilaksankan dimasa pandemi covid 19 dalam memanfaatkan media edukasi untuk mengurangi interaksi langsung dengan masyarakat dalam mencegah perkembangan covid 19 sesuai dengan anjuran pemerintah.

\section{2) Capaian}

Dari 5 kegiatan yang dilaksanakan dimasa pandemic covid 19 pembuatan konten hidroponik memiliki nilai yang lebih tinggi dari tanggapan $97 \%$ responden terhadap kegiatan yang telah dilaksanakan 


\section{Kesimpulan}

Kegiatan yang dilakukan dimasa pandemi covid 19 membutuhkan suatu terobosan teknologi saat ini untuk mensukseskan kegiatan pengabdian yang dilakukan di padarincang dan pabuaran. Dari 5 kegiatan yang dilaksanakan respon yang paling tinggi terdapat pada pembuatan konten inovasi tanaman hidroponik yaitu 97\% tanggapan dari responden.

\section{Penghargaan}

Penulis mengucapkan terima kasih kepada Pemerintah Kecamatan Padarincang yang telah menerima peserta KKM, Universitas Sultan Ageng Tirtayasa Tahun 2020 Kelompok 18 yang berasal dari daerah Kecamatan Padarincang dan Kecamatan Pabuaran. Dr.Rusmana,.Ir.,MP yang telah memberikan kesempatan untuk saya membimbing mahasiswa KKM Reguler Universitas Sultan Ageng Tirtayasa Tahun 2020. Serta semua pihak mahasiswa KKM kelompok 18 Universitas Sultan Ageng Tirtayasa Tahun 2020 yang telah terlibat langsung dalam pelaksanna KKM regular .

\section{Daftar Pustaka}

Cohen, L., Manion, L., Morrison, K., \& Publishers, R. (2014). Book Reviews Research Methods in Education ( 6th ed ), (January 2000).

Devet, B. (1990). A method for observing and evaluating writing lab tutorials. Writing Center Journal, 10(1), 75-83.

Hariyanto, B. (2020). Pengembangan masyarakat berwirausaha desa pasauran kecamatan cinangka kabupaten serang banten, 2(1), 48-55.

Nala, I., \& Indriani, N. (2020). Pengembangan Ekowisata Sungai Berbasis Masyarakat di Desa Pela kutai Kartanegara, Kalimantan Timur. Journal of Tourism and Creativity, 4(2), 8594.

Papini, D. R., Studies, F., \& Building, E. (1988). An Observational Study of Affective and Assertive Family Interactions During Adolescence, 17(6), 477-492.

Rahayuningsih, Y., Budiarto, S., Isminingsih, S., Banten, B. P., Sultran, U., Tirtayasa, A., ... Sukaratu, D. (2019). Peran Bumdes Dalam Penguatan Ekonomi Desa Sukaratu Kabupaten Serang, Banten The Role Of Village Owned Enterprise In Strenghtening The Economic Of Sukaratu Village, Serang Regency, Banten Province, (2).

Saruri, A. (2018). Inovasi Kebijakan Partisipasi Publik dalam Pengelolaan dan Pengembangan Pariwisata (Studi pada Lokasi Ekowisata Situterate Desa Situterate Kecamatan Cikande Kabupaten Serang). Jurnal Administrative Reform, 6(3), 110-121. 